\title{
DUNCAN v. BADDELEY: \\ RECONCILING THE "LOST YEARS" DEDUCTION WITH FATAL ACCIDENT CASES
}

\section{CARA L. BROWN}

\section{INTRODUCTION}

The "lost years" deduction arises in a relatively small number of injury cases. However, with the recent Alberta Court of Appeal decision in Duncan Estate v. Baddeley,' it can be expected that there will be more cases where the lost years deduction will be an important aspect of the calculation process. The method of calculating the lost years deduction has been debated in a number of Canadian cases. The purpose of this note is to explore the various methods used and offer new information to assist in calculating the lost years deduction. Also, the lost years deduction calculation (when estimating damages using the Duncan methodology) is reconciled vis-à-vis dependency loss calculations in fatal accident cases.

\section{THE LOST YEARS CALCULATION}

\section{A. THE LOST YEARS DEFINITION}

In cases where life expectancy has either been shortened because of an accident, or terminated because of an accident (as in Duncan), the courts have determined that compensation should be awarded for the plaintiff's earnings forgone from the time of death to the projected date of retirement. However, if the full amount of lost income were replaced, the plaintiff would be overcompensated. In other words, the courts have determined that a deduction has to be made for all personal living expenses which would have been incurred by the plaintiff to sustain his or her livelihood during the lost years (from the time of death to projected retirement, generally at age 60 ). Thus, the definition of the lost years can be simplified to:

If an injury has shortened the plaintiff's expected work life, then the lost years are those years in which the plaintiff would be earning income (if uninjured) but would no longer be alive to spend it.

For example, if the plaintiff is expected to die at 25,30 or 35 years of age, then the lost years deduction occurs from his or her 25th, 30th, or 35th birthday to his or her estimated retirement age in the absence of the accident and assuming normal mortality. Hence, the present value of living expenses for 35,30 or 25 years will be deducted

M.A.; Principal, Brown Economic Assessments Inc., Calgary, Alberta. The author gratefully acknowledges the research assistance of Joanna Chang in the preparation of this note, and the helpful comments of Constance L. Taylor at Cook Duke Cox, Edmonton, Alberta.

1 (1997), 196 A.R. 161 (Alta. C.A.) [hereinafter Duncan]. Application for leave to appeal to the Supreme Court of Canada filed 3 June 1997 ([1997] S.C.C.A. No. 315 (QL)). 
from the present value of plaintiff's lifetime earnings, assuming pre-accident retirement at age 60 .

\section{B. METHODS OF ASSESSMENT}

There are three methods of calculating the lost years deduction. These methods include the Basic Necessities approach, the Standard of Living approach, and the Savings approach. From the various court decisions, it is not clear whether the deduction should be based on an absolute threshold which does not vary with income level (basic necessities method) or if it should be relative to the plaintiff's potential standard of living as referenced by his or her earning capacity (standard of living). Alternatively, it has been suggested that the only income available to an individual after maintaining his or her standard of living is the amount which would have been saved (savings approach). Figure 1 below is a continuum that illustrates these three methods in terms of the percentage deduction from lifetime earnings.

Figure 1

CONTINUUM OF APPROACHES

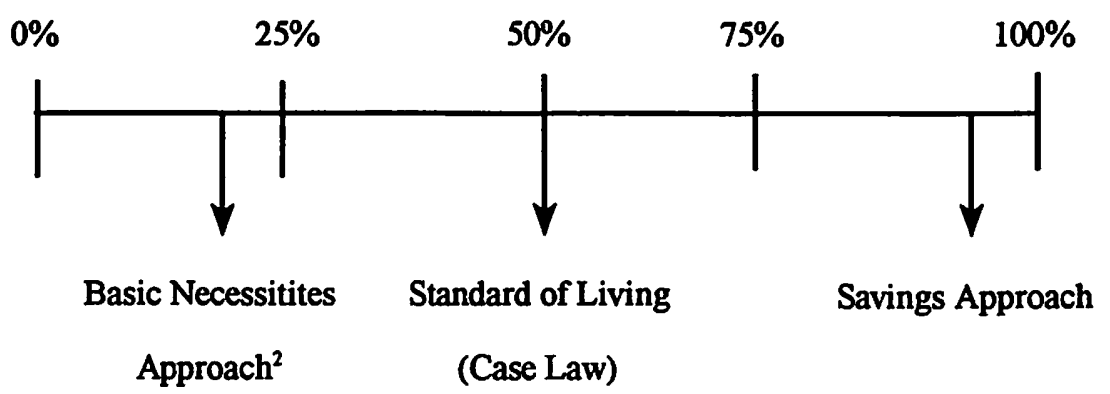

\section{Basic Necessities Approach}

In his article "The 'Lost Years' Deduction," Chris Bruce proposes to deduct $\$ 6,500$ per year for a single person and $\$ 15,000$ per year for a family of four. These amounts are to be applied to the lost years calculations regardless of differences in the level of income of the plaintiffs. According to Bruce, this would mean that if a single plaintiff's income would have been $\$ 20,000$ per year during the lost years, 32.5 percent would have been spent on necessities; while if that plaintiff's income would have been $\$ 50,000$, only 13 percent would have been spent on those items. ${ }^{3}$

Bruce based his position on a book that details a method of calculating the cost of the basic necessities of life for families of various sizes in different regions of Canada. ${ }^{4}$ Bruce argues that the term "basic necessities" as used by Christopher Sarlo in Poverty

Calculated on the basis of 13 percent to 32.5 percent, as per C. Bruce, "The 'Lost Years' Deduction" (1996) 42 The Barrister 22.

$3 \quad$ Ibid. at 23.

$1 \quad$ C. Sarlo, Poverty in Canada (Vancouver: Fraser Institute, 1992). 
in Canada ${ }^{5}$ matches the definitions used by the courts and hence his analysis would provide the best estimate. $^{6}$

This approach is problematic. First, economic theory states that the marginal propensity to consume is a function of income. In other words, people increase their expenditures when income increases, although the correspondence is not always one-toone (e.g. Table 2 below shows that households devote varying proportions of income to the same expenses depending on income level). Thus, level of income cannot be ignored when analyzing a person's expenditure decisions. Second, Bruce used only one source for estimating living expenses. Other sources such as Statistics Canada's Family Expenditure in Canada ${ }^{7}$ and the National Council of Welfare (NCW) estimates of Statistics Canada's Low Income Cut-offs ${ }^{8}$ provide figures that are more representative of the actual dollar spent because expenditure figures are categorized according to income level, family size, and urban population. For cities with more than 500,000 persons, NCW estimates that $\$ 16,175$ was required in 1996 to maintain a minimal standard of living (i.e., poverty threshold) for one person. This figure rises to $\$ 32,089$ for a family of four.' Based on income levels according to education level, the deduction for a one to four-person household (using the NCW thresholds) would range from 42 percent to 84 percent for high school graduates; 39 percent to 77 percent for college graduates; and 30 percent to 56 percent for the bachelor's or master's graduates. The latter percentages more closely resemble the courts' deductions for lost years when the plaintiff had dependents to support.

Finally, as the following discussion will show, Bruce's method is inconsistent with the majority of current jurisprudence.

\section{Standard of Living (Case Law)}

The first case in Canada that dealt with the deduction for basic necessities when calculating loss of prospective earnings was Ontario v. Jennings. Judson J. remarked that

[The estimate of future income earning capacity] must be made in relation to his net income, account being taken of expenditures necessary to earn the income. But income tax is not an element of cost in eaming income. ${ }^{10}$

E.g., ibid. at 49.

Bruce, supra note 2 at 23.

E.g. Statistics Canada, Catalogue 62-555 Occasional, Family Expenditure in Canada - 1992 (Ottawa: Minister of Industry, Science and Technology, 1994) [hereinafter Family 1992].

- National Council of Welfare, Estimates of Statistics Canada's Low Income Cut-Offs (1986 Base) for 1996 (Ottawa: National Council of Welfare, 1995).

Ibid.

$10 \quad$ (1966), 57 D.L.R. (2d) 644 at 656 (S.C.C.). 


\section{More specifically, Dickson J. held in Andrews v. Grand \& Toy Alberta Ltd. that}

a deduction must then be made for the cost of such basic necessities when computing the award for loss of prospective earnings, i.e., the award is on the basis of net eamings and not gross earnings.... The trial judge took ... [this] approach, reducing loss of future earnings by $53 \%$."

The following cases can be divided between those which advocate a deduction based on the standard of living (e.g. income level) of the plaintiff, and those which argue for a deduction for basic necessities only (implying that there is a fixed subsistence level required irrespective of income level). For instance, in Gammell v. Wilson, the House of Lords commented that

the loss to the estate is what the deceased would have been likely to have available to save, spend or distribute after meeting the cost of his living at a standard which his job and career prospects at time of death would suggest he was reasonably likely to achieve. ${ }^{12}$

In this case, the Lords used a deduction ranging from 25 to 33 percent (based on whether or not the plaintiff lived away from home or with his parents). However, it should be noted that, with respect to a young child, the Lords in Gammell also stated that

in cases such as the present, in each of which the deceased was a young man with no established earning capacity or settled pattern of life ... it is hardly possible to make a reasonable estimate of his probable earnings during the 'lost years' and it is, I think, quite impossible to take the further step of making a reasonable estimate of the free balance that would have been available above the cost of maintaining himself throughout the 'lost years', and the amount of that free balance is the relevant figure for calculating damages. ${ }^{13}$

In the case of a young child, the lost years of earning capacity will ordinarily be so distant that assessment is mere speculation. No estimate being possible, no award, not even a 'conventional' award, should ordinarily be made. ${ }^{14}$

\section{In Harris v. Empress Motors Ltd, the English Court of Appeal held that}

the sum to be deducted as living expenses is the proportion of the victims' net earnings that he spends to maintain himself at the standard of living appropriate to his case...the deduction for living expenses to be made in the case of a young unmarried man for the purpose of assessing the recoverable damages for his loss of earnings in the lost years is likely to be higher than in the case of an older married man because it is more easy to estimate the amount which should not be deducted from net earnings in the

(1978), 83 D.L.R. (3d) 452 at 468 (S.C.C.).

[1981] 1 All E.R. 578 at 593 (H.L.) [emphasis added].

Ibid. at 588.

Ibid. at 593. 
case of an older married man than in the case of a young unmarried man whose future is speculative. ${ }^{\text {is }}$

The only guideline the House of Lords offered with respect to the deduction in this case, however, was to say that when there is only one dependent, 50 percent of the joint expenditures should be deducted (presumably in conjunction with the deceased's personal expenses); whereas if there are three dependents, only 25 percent of the joint expenditures should be deducted (again, presumably in addition to the deceased's personal expenses). ${ }^{16}$

The British Columbia Court of Appeal relied upon the Harris decision in Semenoff v. Kokan to estimate the deduction for living expenses in the plaintiff's lost years due to a shortened life expectancy. ${ }^{17}$ The decision in Semenoff took into account that the plaintiff was a married man who would have had two children. The Court came to the following conclusion:

In the absence of precise figures, I think we are justified in accepting the conventional deduction of $33 \%$ discussed in Harris. Accordingly, I would allow the appeal and vary the judgment by deducting $33 \%$ from the damages for the lost years. ${ }^{18}$

However, in two more recent B.C. decisions, the wording pertaining to the lost years deduction changed to "basic necessities," although similar percentages were still applied. In an unpublished decision, Bastian v. Mori, Hood J. found that

it is appropriate to deduct from the amount ascertained the amount that Danny would have expended on the basic necessities of life while earning that income. ${ }^{19}$

Counsel for the defendant argued that the hypothetical amount Danny would have spent on food, shelter and other necessities during the lost years was $53.3 \% .^{20}$

In any event I am satisfied on the evidence before me that $53 \%$ rounded off fairly represents Danny's "costs of living" which he would have expended while earning his future income from age 30 to age $65^{21}$ 
Another recent British Columbia decision, in which the Supreme Court quoted from Bastian $^{22}$ and the Court of Appeal followed Semenoff, ${ }^{23}$ is Toneguzzo-Norvell v. Burnaby Hospital. The interchanging of "basic necessities" with "personal expenses" in these decisions complicates the definition of the deduction to be made. At the trial level, Hogarth J. referred to the trial judge's decision in Bastian to deduct "that which the Plaintiff would have had to spend on basic needs." ${ }^{24}$ In the end, the trial judge did not make a deduction for personal expenses during the lost years, but this decision was reversed on appeal and a deduction of 50 percent was implemented.

However, whereas the trial judge referred to "basic needs" (although a deduction was not made), the Court of Appeal changed this phrase to "personal expenses" and recognized in the evidence of the economist who testified for the plaintiffs in this case that such expenses varied with income level. ${ }^{25}$ The Supreme Court of Canada affirmed the B.C. Court of Appeal's calculation of the lost years deduction and referred to "personal expenses":

There can be no capacity to earn without a life. The maintenance of that life requires expenditure for personal living expenses. Hence the earnings which the award represents are conditional on personal living expenses having been incurred. It follows that such expenses may appropriately be deducted from the award. ${ }^{26}$

It is of importance to note that although the Supreme Court maintained the Court of Appeal's deduction of 50 percent from the award for lost earning capacity, reference to the function of the award pertains to its small magnitude in the case of a child:

The logic of the making of a deduction for personal living expenses on the lost years in the case of a child is also supported by the argument that since Jessica's care is fully provided for under another head of the award, the award for lost eaming capacity will serve but one purpose: to enrich her heirs. It will do little to improve her life. As Cooper-Stephenson and Saunders persuasively argue in Personal Injury Damages in Canada (1981), at p. 244, the amount by which heirs can ordinarily expect to be enriched by a victim's putative earnings is small indeed:

...the award of damages to a very young child for prospective loss of earnings during the lost years, should reflect only that portion of the entire lifetime earnings which the court estimates would have been saved by the child for his estate, at the end of his pre-accident life expectancy. It may result in a very small award. ${ }^{27}$

Toneguzzo-Norvell v. Burnaby Hospital, [1991] B.C.J. No. 2206 (B.C.S.C.) (QL) [hereinafter Toneguzzo (B.C.S.C.)].

Toneguzzo-Norvell v. Burnaby Hospital (1992), (1993) 73 B.C.L.R. (2d) 116 at 128 (para. 42) (B.C.C.A.) [hereinafter Toneguzzo (B.C.C.A.)].

Toneguzzo (B.C.S.C.), supra note 22 at 20.

Toneguzzo (B.C.C.A.), supra note 23 at $129-30$ (paras. 49-52).

Toneguzzo-Norvell v. Burnaby Hospital (1994), 87 B.C.L.R. (2d) 1 at 10 (para. 28) (S.C.C.) [hereinafter Toneguzzo (S.C.C.)].

Ibid. at 10 (para. 30). 
The Supreme Court's decision to retain the 50 percent deduction in Toneguzzo appears to be at odds with a deduction based on savings accumulated by a person's estate prior to death - particularly as the present value of this deduction would presumably be calculated near the end of the person's pre-accident normal life expectancy, rather than evenly throughout the lost years period (from the expected date of death, post-accident, to pre-accident retirement).

There are several cases involving the lost years calculation due to shortened life expectancy from birth. One such case is Duncan v. Kemp. The Court referred to Lord Wilberforce's decision in Pickett v. British Rail Engineering Ltd.:28

\begin{abstract}
...the amount to be recovered in respect of earnings in the "lost" years should be that amount after deduction of an estimated sum to represent the victim's probable living expenses during those years. I think that this is right because the basis, in principle, for recovery lies in the interest which he has in making provision for dependants and others, and this he would do out of his surplus.
\end{abstract}

Taking into account money spent to live while earning an income would seem to result in the beneficiaries receiving their full entitlement. To not apply any deductions and theoretically allow the full amount to go to the estate would result in a windfall.

The decisions involved in this issue mention a 53 percent deduction as a conservative figure. I order a 53 percent deduction to be made from the wages for the "lost years". Presumably counsel will agree on the calculations. ${ }^{29}$

The Court thus ordered a 53 percent deduction to be made from the wages for the lost years. Similarly, in Sigouin v. Wong, the action was for damages for negligence in prenatal care of the mother of an infant plaintiff born spastic in all four limbs, incontinent, moderately mentally retarded, with a seizure disorder and inability to speak, all owing to significant brain abnormalities. Melvin J. made the following comments about the lost years deduction:

Based on the evidence of the witnesses plus the literature which they have discussed, I am satisfied that the evidence causes me to conclude that the infant plaintiff will not survive as long as the witnesses for the infant plaintiff suggest. The preponderance of the evidence demonstrates that the infant plaintiff is unlikely to live beyond the age of 35 years. I accept this evidence. ${ }^{30}$

After considering a variety of authorities our Court of Appeal in Semenoff stated...:

"In my view, we must make a suitable deduction for the total sum that Mr. Semenoff would have been likely to spend on himself during the lost years." [Emphasis added.] 
Accepting that statement, a determination of the amount to be deducted is necessary. In Semenoff, as in the case at bar, the court had no precise figures and concluded at p.7...:

"We know, however, that in this hypothetical calculation living expenses must be present. In the absence of precise figures, I think we are justified in accepting the conventional deduction of 33 percent discussed in Harris.

Accordingly I would allow the appeal and vary the judgment by deducting 33 per cent from the damages for the lost years."

The deduction in Kemp was without regard to whether the child plaintiff was single or had dependents. In Dube v. Penlon Ltd., the three year old plaintiff suffered diffuse brain damage and was rendered quadriplegic as a result of anaesthetic overdose during a minor surgery. Zuber J. commented:

Jorden Dube is entitled to be compensated for his lost earnings to be calculated from age 18 to 65 . From 18 to 55 (his life expectancy) deductions must be made to eliminate double counting. It now appears that deductions must also be made from the wages he would have made from 55 to 65 . These years are sometimes referred to as the "lost years."

The problem in deciding the percentage deduction was explained by Professor Carr in his evidence.... He illustrated ... with the example of a person who expends all of his income on a comfortable home, fine dining and a handsome lifestyle and then asks if it could be said that this person during the lost years would have suffered no loss of income. Professor Carr's evidence in my view supports a somewhat smaller deduction for the lost years, and I conclude that a deduction of $1 / 3$ for the lost years would be reasonable. ${ }^{32}$

Zuber. J's conclusion implies a 33 percent deduction. In Kemp, Sigouin and Dube, the courts do not make explicit comments regarding the phrases "basic necessities" or "standard of living."

Since the Toneguzzo decision, six additional decisions have discussed the lost years deduction. In Pittman Estate v. Bain, Lang J. applied a deduction of 40 percent in her consideration of the lost years concept. ${ }^{33}$ In Granger v. Ottawa General Hospital, Cunningham J. again used the term "living expenses" when defining the lost years deduction:

Some deduction must be made to account for living expenses during the "lost years". In a situation such as this where a person is not expected to live his or her normal life expectancy, if we were to replace the full amount of that person's lost income for their working life expectancy, that person would be over compensated because it would not take into account the personal living expenses which would have been incurred during the "lost years"34

$31 \quad$ Ibid. at $279-80$ (paras. 109-10).

32 (1994), 21 C.C.L.T. (2d) 268 at 280-81 (paras. 48-50) (Ont. Gen. Div.).

33 (1994), 112 D.L.R. (4th) 257, supplementary reasons for judgment at (1994), 112 D.L.R. (4th) 482

(Ont. Gen. Div.).

$4 \quad$ [1996] O.J. No. 2129 at para. 205 (Ont. Gen. Div.) (QL). 
In my view there is no precise way of measuring such a deduction and it is for a court on the basis of the evidence before it to apply what it considers to be an appropriate deduction. ${ }^{35}$

Having taken into account all of the cases to which I have referred, the unique facts of this case and the evidence of the experts I conclude that an appropriate deduction would be 70 percent. $^{36}$

In Webster v. Chapman, MacInnes J. considered the case of a 12-year-old girl who would live until age 27 . In this instance, the judge did not make an award at all for the lost years (age 27 to retirement at 61):

I conclude that her level of income is such that the substantial majority of her income would necessarily have been used in the course of her day to day living, and little would remain thereafter. In Toneguzzo the Supreme Court of Canada adopted the Savings Approach, which in my view, is the most realistic approach in quantifying the income loss for the lost years.... In the circumstances, I am not prepared to allow any amount of compensation under this heading. ${ }^{37}$

Similarly, in Marchand v. Public General Hospital, Granger J. discussed many decisions, including Gammell, Toneguzzo, Pittman and Granger and came to the conclusion that:

I cunclude that logical and functional considerations combine to suggest that it is appropriate to make a deduction for personal living expenses from the award for lost earning capacity during the "lost years".

I would allow the appeal in part ... I would maintain the Court of Appeal's deduction of $50 \%$ from the award for lost earning capacity.

Accordingly, notwithstanding my misgivings of awarding damages for lost income during the "lost years", I am bound to follow the dictates of the Supreme Court of Canada and make such an award. ${ }^{38}$

In Brown v. University of Alberta Hospital, Marceau J. supplied a rationale for rejecting the savings approach:

For the defence, Dr. Pesando was called to provide evidence before this court. He took the position that it is not possible to determine the extent of living expenses that would be spent by one individual, with the result that personal living expense deductions are highly speculative. In contrast, he asserted that once the income of an individual has been projected, the saving rate can be accurately predicted.... Both defendants, in urging me to adopt a lost savings approach, ask me to accept Dr. Pasando's evidence that a lost savings approach should result in a $98.2 \%$ reduction of the award. 
I am not persuaded by the arguments of the defense. All lost year awards contain a high degree of speculation, however, this is in no way a valid reason for denying or reducing such awards. It is trite law that difficulty in assessing damages is not a bar to recovery.

Moreover, the defendant physicians' argument that the lost savings approach most accurately reflects the amount this plaintiff would have left to her heirs reveals the fundamental flaw of the lost years approach. The latter shifts the focus from compensating the plaintiff for her loss to compensating the heirs or dependants for their loss. This is an action to compensate Nadine Fogh for the loss she has suffered as a result of this tragedy. It is not, for example, a claim under the Fatal Accidents Act by her dependants. To quantify damages based on what her heirs would have received is to account for improper and irrelevant considerations.

In rejecting the lost savings approach, I acknowledge that three of the four cases post-Toneguzzo cases (Webster et al. v. Chapman et al., [1996] M.J. No. 384; 114 Man. R. (2d) 1 (Q.B.); Granger et al. v. Ottawa General Hospital et al., [1996] O.J. No. 2129; 7 O.C.T. 89 (Gen. Div.); and Marchand v. Public General Hospital, [1996] O.J. No. 4420 (Gen Div) (Q.L.)) have adopted the lost savings approach. Surely I should not hold, without more, that a lost savings approach must be correct because it has been applied three times, whereas the personal living expense deduction has only been applied once. I can find nothing more that commends the lost savings approach to me.

Having rejected the lost savings approach, I turn now to determine the proper deduction that should be made for personal living expenses. In this regard, it is significant that all four of the post-Toneguzzo decisions find that the latter does not stand for the proposition that a $50 \%$ deduction must be made; rather, the cases all take the position that the proper deduction must be assessed on a case-by-case basis.

The semblance of the awards for loss of future income support a finding that a similar amount of $1 / 3$ should be deducted in this case. I note that a $1 / 3$ deduction corresponds with the conventional $33 \%$ deduction. This affirms me that this is the correct approach, in that I find there is nothing unique about this case that would warrant a departure from the conventional deduction. ${ }^{39}$

In a recent case, Duncan, the Alberta Court of Appeal also considered the lost years methodology and rejected the savings approach, as Marceau J. did in Brown. The Court's reasoning is reproduced below:

The trial judge adopted the view that the net effect of that rule is to limit the award to a calculation of the present value of the expected life-savings of the victim. In sum, what he would have kept and left for his heirs is a fair measure of how much of his earnings he would have not spent in his lifetime. The appellant contended before us that the correct means of calculating the offsetting saved expenses was to use the yardstick of "basic need". The respondent replied that the trial judge had correctly understood the rule in Toneguzzo-Norvell.

In my view, neither is the correct approach. I agree that, at first sight, what I spend in a given year is what I would not have spent if I had not been around to spend it. And I agree that a lifetime accumulation of what I did not spend is likely what I will have in my estate at death. I further agree 
that what I spend on capital items, i.e. what was of enduring value, should, if any value indeed endures until death, also be reflected in my estate.

Nevertheless, it seems to me that this would not be a correct statement of what I earned in my lifetime. My life-savings would not tell one what I spent during my life on my pleasure, as opposed to what I had to spend in connection with the earning of my income.

The flaw in the "lost savings" approach is that it is heir-centered, not victim-centred. It asks what the heirs lost, not what the victim lost. But the suit here is not for the loss to the estate, it is a suit by the victim for his loss, a claim that by operation of statute survives his death and can be made by his estate for him. Worse, it has the air about it of an attempt to undermine the statute. As a result of this flaw, the approach will fail to take into account what has been called "discretionary" spending, like holidays and entertainment and other "treats". It will also fail to take into account gifts to children and spouses, and thereby underestimate even an heir-centred award. ${ }^{40}$

I conclude that logical and functional considerations combine to suggest that it is appropriate to make a deduction for personal living expenses from the award for lost earning capacity during the "lost years" (emphasis added)."

It was said for the appellant that I am bound to seek out only what would have been the cost of "basic necessities" had the victim lived. My impression was that what was sought was some sort of povertyline calculation - the amount required to spend to avoid starvation and remain sufficiently healthy to work. It was suggested that this was the approach for calculation of living expenses taken by the Supreme Court of Canada in Andrews v. Grand and Toy. I do not agree. ${ }^{42}$

In my view, the law requires that we calculate the expenses that the victim would have incurred in the course of earning the living we predict he would earn. That sum will vary with the kind of employment, and the state in life of the victim. Neither "poverty-line" expenses nor "lost savings" are a reliable indicator of that sum. Rather, it should be a fair calculation of the likely future cost of lives.

Cases suggest a discount of $50 \%$ to $70 \%$. My sense of the matter is that this is an apt range. But I suggest that expert evidence could help the judge to assess this cost. The plaintiff actuary here did no calculation. He instead accepted $50 \%$ or that "suggested by the cases". Again, that calculation should include one for tax. ${ }^{3}$

Table 1 below summarizes the basis for the deductions and magnitude of deductions in the case law. 
Table 1

\section{SUMMARY OF DEDUCTIONS FOR \\ BASIC NECESSITIES/STANDARD OF LIVING, CASE LAW}

\begin{tabular}{|c|c|c|c|}
\hline Case & $\begin{array}{l}\text { Basis for } \\
\text { Deduction }\end{array}$ & $\begin{array}{l}\% \text { deduction } \\
\text { for single } \\
\text { person }\end{array}$ & $\begin{array}{l}\% \\
\text { deduction } \\
\text { for person } \\
\text { with } \\
\text { dependents }\end{array}$ \\
\hline Ontario v. Jennings (1966) & N/A & N/A & N/A \\
\hline Andrews v. Grand \& Toy Alberta Ltd. (1978) & Basic necessities & $53 \%$ & N/A \\
\hline Gammell v. Wilson (1981) & Standard of living & $33 \%$ & $25 \%$ \\
\hline Harris v. Empress Motors Ltd. (1983) & Standard of living & $50 \%$ & 25 to $33 \%$ \\
\hline Bastian v. Mori (1990) & Basic necessities & $53 \%$ & N/A \\
\hline Semenoff v. Kokan (1991) & Standard of living & N/A & $33 \%$ \\
\hline Duncan v. Kemp (1991) & Standard of living & $53 \%$ & N/A \\
\hline Sigouin v. Wong (1991)* & Standard of living & $33 \%$ & N/A \\
\hline Dube v. Penlon Lid. (1994) & Basic necessities & $33 \%$ & N/A \\
\hline $\begin{array}{l}\text { Tonegguzzo-Norvell v. Burnaby Hospital } \\
\text { (1994) }\end{array}$ & Standard of living & $50 \%$ & N/A \\
\hline Pittman Estate v. Bain (1994) & Standard of living & $40 \%$ & N/A \\
\hline Granger v. Ottawa General Hospital (1996) & Standard of living & $70 \%$ & N/A \\
\hline Webster v. Chapman $(1996)^{* *}$ & Basic necessities & N/A & N/A \\
\hline Marchand v. Public General Hospital (1996) & Standard of living & $50 \%$ & $\mathrm{~N} / \mathrm{A}$ \\
\hline Brown v. University of Alberta Hospital (1997) & Standard of living & $33 \%$ & N/A \\
\hline Duncan Estate v. Baddeley (1997) & Standard of living & $50 \%-70 \%$ & N/A \\
\hline
\end{tabular}

* In Sigouin, the deduction was without regard to whether the plaintiff was single or had dependents.

** In Webster, MacInnes J. did not make an award during the lost years at all.

Most cases have used standard of living as the basis of deduction. Even when the courts used the basic necessities method, they nevertheless employed a deduction of 53 percent, but this average does not include Semenoff, which only considered a deduction for an individual with dependents; or Webster, in which the judge did not make a deduction during the lost years.

The percentage deductions used in the cases summarized in Table 1 are lower than the standard of living normally associated with typical expenditures by income level. Table 2 summarizes the percentage of income devoted to food, shelter, household operations and furnishings, clothing, transportation, health care, personal care, recreation, reading, education, tobacco and alcohol, and miscellaneous expenditure categories based on data collected by Statistics Canada. Then it derives the ratio of consumption to expenditure for various household income levels in the prairie provinces with 1.95 to 3.22 members per household. 
Table 2

PRAIRIE PROVINCES, CONSUMPTION/EXPENDITURE BY INCOME LEVEL, $1992^{44}$

\begin{tabular}{llll} 
Income Level & $\begin{array}{l}\text { Total Current } \\
\text { Consumption* }\end{array}$ & $\begin{array}{l}\text { Total } \\
\text { Expenditure* }\end{array}$ & $\begin{array}{l}\text { \% Consumption/ } \\
\text { Expenditure }\end{array}$ \\
\hline$\$ 15,000-\$ 19,999$ & $\$ 17,115$ & $\$ 19,526$ & $87.65 \%$ \\
$\$ 20,000-\$ 29,999$ & $\$ 22,648$ & $\$ 28,014$ & $80.85 \%$ \\
$\$ 30,000-\$ 39,999$ & $\$ 27,668$ & $\$ 36,443$ & $75.92 \%$ \\
$\$ 40,000-\$ 49,999$ & $\$ 33,419$ & $\$ 45,167$ & $73.99 \%$ \\
$\$ 50,000-\$ 59,999$ & $\$ 35,955$ & $\$ 52,003$ & $69.14 \%$ \\
$\$ 60,000-\$ 79,000$ & $\$ 43,990$ & $\$ 65,780$ & $66.87 \%$ \\
\hline AVERAGE & & & $75.74 \%$ \\
\hline
\end{tabular}

Includes food, shelter, household operation \& furnishings, clothing, transportation, health \& personal care, recreation, reading materials, education, tobacco \& alcohol, and miscellaneous costs.

** Includes all items in Total Current Consumption plus personal income taxes and costs for security and gifts \& contributions.

Table 2 shows that, not surprisingly, lower income households have to devote more of their income to maintaining their standard of living, while higher income households have more discretionary income. The overall average percentage, 75.74 percent, is still considerably higher than the 25 to 53 percent range used by the courts, however. Indeed, the courts' deduction would only include expenditures on food, shelter, clothing, public transportation, and health care. ${ }^{45}$ The 75.74 percent includes many consumed items which would not necessarily be considered as "basic necessities." Nonetheless, it must be remembered that the consumption figures shown in Table 2 are for households with two to three people.

\section{Savings Approach}

One potential method to calculate the portion to be deducted as personal expenses is to use the inverse of the savings rate. ${ }^{46}$ Data on savings rates indicates that the overall Canadian savings rate averaged 11.7 percent from 1977 to $1994,{ }^{47}$ suggesting a deduction of 88.3 percent $(=100$ percent -11.7 percent).

Source: Family 1992, supra note 7, Table 12.

Calculations based on Statistics Canada, Catalogue 62-555, Family Expenditure in Canada - 17 Metropolitan Areas 1990 (Ottawa: Minister of Industry, Science and Technology, 1992), Tables $4,15,16$.

46 Another method would be to project the value of the deceased's estate. There appears to be only one study which would publish statistical estimates of the value of estates: Statistics Canada's Canadian Asset and Debt Survey. Statistics Canada intends to conduct a survey on the average value of estates inherited but does not anticipate having results published until 1998.

Based on historical saving rates from 1977 to 1994 in Statistics Canada, Catalogue 11-210, Canadian Economic Observer 1994/1995 (Ottawa: Minister of Industry, Science and Technology, 1995), Table 2 [hereinafter Canadian Economic Observer]. 
Using an economic forecast, the average savings rate is projected for a period of 20 years from 1995 onward $^{48}$ to be 7.1 percent with a standard deviation of about 0.8 percent. Hence, according to the inverse savings rate formula, the deduction for personal expenses would range from 88 percent to 93 percent (See Tables A1 and A2 in Appendix A).

It is evident from a review of the case law in Table 1 that there have been no cases which have adopted the savings approach. Morever, the Alberta Court of Appeal rejected this approach in Duncan.

\section{LOST YEARS DEDUCTION: RECOMMENDATION}

Based on the above-mentioned case law and taking into consideration the data discussed above, it is submitted that a 50 percent deduction, in the absence of detailed evidence regarding the "available surplus" left by the plaintiff, is appropriate. The magnitude of this deduction reconciles family status (single or married) but allows for dependents in the future; and it also captures the tendency for people's "basic necessities" or "personal expenses" incurred to earn a living to fluctuate with their income level, a concern expressed in some of the case law reviewed above and a trend consistent with economic theory. Finally, it is consistent with the most recent Alberta Court of Appeal decision, Duncan, and the Supreme Court of Canada decision in Toneguzzo, and lies in the midpoint of the 25 percent to 70 percent range shown in Table 1.

\section{RECONCILING THE LOST YEARS CALCULATION WITH DEPENDENCY LOSS CALCULATIONS}

\section{A. THE LOST YEARS METHODOLOGY}

The methodology for estimating loss of income on the basis of Duncan is as follows:

In my view, the law requires that we calculate the expenses that the victim would have incurred in the course of earning the living we predict he would earn. That sum will vary with the kind of employment, and the state in life of the victim. Neither "poverty-line" expenses nor "lost savings" are a reliable indicator of that sum. Rather, it should be a fair calculation of the likely future cost of lives.

Cases suggest a discount of $50 \%$ to $70 \%$. My sense of the matter is that this is an apt range. But 1 suggest that expert evidence could help the judge to assess this cost. The plaintiff actuary here did no calculation. He instead accepted $50 \%$ or that "suggested by the cases". Again, that calculation should include one for tax. 
Additionally, in this case, there should be a discount for the chance that the victim would not receive the optimal award calculated by the plaintiff's actuary.9

The methodology outlined in Duncan is similar to the procedure used in calculating dependency losses in fatal accident cases. Notably, a deduction for the deceased's income taxes is recommended in Duncan, as is the case when calculating dependency losses under the Fatal Accidents Act. $^{\text {so }}$

However, the recommended deduction for taxes is similar to the procedure in wrongful death cases, but contrary to the practice of ignoring income taxes in personal injury cases. It also represents a departure from other personal injury cases in which life expectancy is shortened but not terminated. There the lost years deduction is still applied but income taxes are ignored. Table 3 summarizes these differences.

Table 3

PROCEDURES FOR CALCULATING DAMAGES IN PERSONAL INJURY AND FATAL ACCIDENT CASES

\begin{tabular}{|l|l|l|l|l|}
\hline $\begin{array}{l}\text { Type of Cases } \\
\text { Litigated }\end{array}$ & $\begin{array}{l}\text { Apply Lost Years } \\
\text { Deduction? }\end{array}$ & Deduct Taxes? & Tax Gross-up? & $\begin{array}{l}\text { Housekeeping } \\
\text { Claims } \\
\text { Allowed? }\end{array}$ \\
\hline Personal injury & $\begin{array}{l}\text { Only if life } \\
\text { expectancy is } \\
\text { shortened }\end{array}$ & No & No* $^{*}$ & Yes \\
\hline Wrongful death (FAA) & No & Yes & Yes & Yes \\
\hline Wrongful death (SAA) & Yes & Yes & Not Known & Not Known \\
\hline
\end{tabular}

A tax gross-up is only calculated on costs of future care and sometimes loss of housekeeping capacity.

In cases litigated under The Fatal Accidents Act, the dependency loss is subsequently estimated after taking into account the deceased's share of living expenses, which are no longer required as a result of his or her death. This is conceptually similar to the lost years deduction. It is the rationale for and magnitude of the deduction for the deceased's living expenses which varies in wrongful death cases vis-à-vis cases in which the lost years deduction is applied.

Although the Alberta Court of Appeal in Duncan did not explicitly state the magnitude of the lost years deduction to be used, it is clear that they reject the extremes in the continuum (see Figure 1). As stated above, this note recommends a lost years deduction of 50 percent in the absence of specific evidence. In contrast, personal consumption rates ${ }^{51}$ in fatal accident cases range from 14 percent to 31 percent (see Table 4 below), although the net deduction depends on the relative incomes of the deceased and survivor. This difference is explained and reconciled below. 


\section{B. DEPENDENCY LOSS CALCULATIONS}

Where a claim is made on behalf of a dependent pursuant to The Fatal Accidents $A c t$, a deduction is made to account for the personal consumption of the deceased in order to estimate the survivors' dependency losses, which vary according to family size. Estimates of personal consumption rates are summarized in Table 4 below.

Table 4

PERSONAL CONSUMPTION RATES TO ALLOCATE TO THE DECEASED, DEPENDING ON FAMILY SIZE

\begin{tabular}{llllll} 
Source & $\begin{array}{l}2 \text { adult } \\
\text { family }\end{array}$ & $\begin{array}{l}2 \text { adults, } \\
1 \text { child }\end{array}$ & $\begin{array}{l}2 \text { adults, } \\
2 \text { children }\end{array}$ & $\begin{array}{l}2 \text { adults, } \\
3 \text { children }\end{array}$ & $\begin{array}{l}2 \text { adults, } \\
4 \text { children }\end{array}$ \\
\hline${\text { Cheit }(1961)^{52}}^{53}$ & $30.0 \%$ & $26.0 \%$ & $22.0 \%$ & $20.0 \%$ & $18.0 \%$ \\
King and Smith (1988) & $23.4 \%$ & $21.7 \%$ & $17.7 \%$ & $16.4 \%$ & $13.7 \%$ \\
Bruce (1992) & $30.0 \%$ & N/A & $17-24 \%$ & N/A & $15.0 \%$ \\
$\begin{array}{l}\text { Department of Labor (U.S.), } \\
\text { 1994ss }\end{array}$ & $40.0 \%$ & $30.5 \%$ & $24.0 \%$ & $17.2 \%$ & $11.4 \%$ \\
$\begin{array}{l}\text { Martin (1994) } \\
\text { Brown (1997) }\end{array}$ & $31.0 \%$ & $23.9 \%$ & $20.1 \%$ & $15.1 \%$ & $12.4 \%$ \\
\hline AVERAGE of above sources & 33.28 & 21.00 & 16.28 & $11.97^{58}$ & N/A \\
\hline
\end{tabular}

The percentages summarized in Table 4 suggest that, on average, 31 percent of family income can be attributed to a deceased adult when there is one adult survivor.

Using a personal consumption rate of 31 percent for the deceased adult, the survivor's dependency loss is calculated in the following way:

E. Cheit, Injury and Recovery in the Course of Employment (New York: John Wiley \& Sons, 1961) at 78 (Table 3.5).

53 E.M. King \& J.P. Smith, Computing Economic Loss in Cases of Wrongful Death (Santa Monica, CA: Rand, 1988) at 71 (Table 7.2). These results are specific to the age of the family head (i.e., between 35 and 54). It should be noted that King and Smith's results are actually an average of three methodologies by Orchansky, Lazear and Michael, and the U.S. Bureau of Labor Statistics. C.J. Bruce, Assessment of Personal Injury Damages, 2d ed. (Toronto: Butterworths, 1992). These percentages are calculated by estimating the residual from the dependency rates shown in Table 11.8 at 235 .

United States Bureau of Labor Statistics, Bulletin 1865, Table 154, cited in G.D. Martin, Determining Economic Damages (Santa Ana, CA: James Publishing Group, 1988) at 5-4. Martin, ibid. at 5-4.1. Martin combined the following various U.S. studies to arrive at these estimates: Bureau of Labor Statistics bulletins; research by the Rand Institute, the Urban Institute, and information from numerous other forensic economists in the U.S.

57 Derived from Family 1992, supra note 7, Table 17.

ss This percentage is relatively lower than the other estimates in the same category because it consists of two adults and three or more children.

59 The Bruce figures were not included in this average due to the omitted estimates for 2 adults, 1 child families.

60 The Bruce figures were not included in this average due to the omitted estimates for 2 adults, 3 children families.

61 The Brown figures were not included in this average because Statistics Canada only reports data for families with "three or more" children. 


\section{Dependency loss $=\{[1$-personal consumption rate $] \mathbf{x}$ deceased's income $\}$ - \{personal consumption rate $\mathrm{x}$ survivor's income\}.}

Thus, the first component quantifies the share of the deceased's income, which would have been spent on the survivors; this is then reduced by the second component, which represents the savings to the survivors of the amount they formerly spent on the deceased. The net deduction depends on the relative incomes of the deceased and the survivor. (Table 5 below illustrates net deductions based on various combinations of income levels for the survivor and the deceased.)

In fatal accident cases that are litigated pursuant to The Survival of Actions $A c t^{62}$ (as in Duncan), the deduction is for the basic necessities/living expenses predicted for the deceased - without regard to survivors. Table 1 above showed that the lost years deduction ranged from a low of 25 percent to a high of 70 percent, depending on the case. Interestingly, in cases which carefully considered the impact of a surviving family on the lost years deduction, the lower deduction of 25 percent is similar to personal consumption rates for a deceased adult with one child (see Table 3 above, e.g., 25.5 percent).$^{63}$ However, the average deduction for one adult's living expenses $(50$ percent) is far in excess of personal consumption rates for one adult in Table 3 above (31 percent) ${ }^{64}$ Notably, the personal consumption rate of 31 percent for a deceased adult (assuming the presence of one surviving adult) is much closer to the inverse of percentage of consumption/expenditure shown in Table 2 above (1-75.74 percent $=24.26$ percent).

Personal consumption rates used in fatal accident cases to calculate dependency losses are clearly framed in light of the needs (or "dependency") of the surviving family. As a result, the personal consumption rates used to determine the surviving members' dependency on the deceased's income is calculated based on the fact that the deceased is an incremental member of the household. In other words, because there is a tacit assumption that the family still requires the capital outlay of fixed costs in order to maintain its standard of living (e.g. house (shelter), transportation (car), and furnishings), dependency losses implicitly incorporate compensation for these costs by only deducting the deceased's variable costs (e.g. his/her share of food, gas, clothing, recreation and personal care).

In contrast, the lost years deduction represents all of the basic costs/living expenses (fixed and variable costs) incurred by the deceased to house, clothe and shelter him or her. This is the main reason that the lost years deduction for one deceased individual of 50 percent exceeds the personal consumption rate of 31 percent in fatal accident cases. Despite this difference, which would lead one to infer that the lost years deduction is larger than the implicit deduction made in fatal accident cases, it turns out that in many instances a 50 percent lost years deduction is similar to, and in some cases less than, the deduction applied in fatal accident cases. Table 5 illustrates this 
by calculating hypothetical net deductions in fatal accident cases depending on the deceased and survivor's net incomes.

Table 5

PERCENTAGE 'NET' DEDUCTIONS BASED ON VARIOUS

COMBINATIONS OF INCOME LEVELS FOR SURVIVOR AND DECEASED

(USING PERSONAL CONSUMPTION RATE OF 31 PERCENT

FOR 2-ADULT HOUSEHOLD FROM TABLE 3)*

\begin{tabular}{|c|c|c|c|c|c|}
\hline \multirow{2}{*}{$\begin{array}{l}\text { Net income of } \\
\text { deceased }\end{array}$} & \multicolumn{5}{|c|}{ Net Income of Survivor (after taxes and deductions) } \\
\hline & $\$ 20,000$ & $\$ 30,000$ & $\$ 40,000$ & $\$ 50,000$ & $\$ 60,000$ \\
\hline$\$ 20,000$ & $62.0 \%$ & $77.5 \%$ & $93.0 \%$ & $100+\%$ & $100+\%$ \\
\hline$\$ 30,000$ & $51.7 \%$ & $62.0 \%$ & $72.3 \%$ & $82.7 \%$ & $93.0 \%$ \\
\hline$\$ 40,000$ & $46.5 \%$ & $54.3 \%$ & $62.0 \%$ & $69.8 \%$ & $77.5 \%$ \\
\hline$\$ 50,000$ & $43.4 \%$ & $49.6 \%$ & $558 \%$ & $62.0 \%$ & $68.2 \%$ \\
\hline$\$ 60,000$ & $413 \%$ & $46.5 \%$ & $51.7 \%$ & $56.8 \%$ & $62.0 \%$ \\
\hline \multicolumn{6}{|c|}{$\begin{array}{l}\text { * Percentage 'Net' deduction is calculated from the formula: } \\
=[1 \text {-dependency loss] [deceased income], where: } \\
\text { Dependency loss }=((1 \text {-personal consumption rate }) * \text { deceased income }) \text {-personal consumption rate* } \\
\text { survivor's income }\end{array}$} \\
\hline
\end{tabular}

Table 5 shows that a lost years deduction of 50 percent is comparable to the net deduction arrived at in fatal accident cases when the deceased's income exceeds the survivor's income (shown in the shaded boxes); and at higher income levels when the incomes of both adults are comparable. This occurs because fatal accident calculations contemplate the deceased's share of total household income (i.e., the deceased's and survivor's income combined). ${ }^{65}$

\section{CONCLUSION}

The origin of the initiated claim will determine the magnitude of the deduction because the focus on who is the beneficiary alters the calculation process. In some cases, The Survival of Actions Act claims will result in a larger deduction than The Fatal Accidents Act claims (and hence a smaller award) because there is no regard for fixed expenses already incurred by the deceased (and possibly his or her family). In other cases, Table 5 shows that claims under The Fatal Accidents Act will result in larger deductions (and hence a smaller award) depending on the relativity of the deceased and survivor's incomes.

It has also been suggested that both claims could be advanced (i.e., under both the Survival of Actions Act and the Fatal Accidents Act). In this case, it is argued that standard dependency losses are calculated under the Fatal Accidents Act whereas lost 
savings or inheritance could be calculated under the Survival of Actions Act. However, although it appears that counsel may be able to initiate claims under both Acts, an Australian decision addressing this topic has ruled that any duplication in calculation of damages is to be avoided by deducting such duplication from the awarded damages. ${ }^{66}$ It remains to be seen if these causes of action could be simultaneously successful in Canada. 


\section{APPENDIX A}

Table Al

SAVINGS RATE ${ }^{67}$

HISTORICAL FIGURES (1977- 1994)

\begin{tabular}{|c|c|}
\hline Year & \% Savings Rate* \\
\hline 1977 & 11.2 \\
\hline 1978 & 12.4 \\
\hline 1979 & 12.9 \\
\hline 1980 & 13.3 \\
\hline 1981 & 15.0 \\
\hline 1982 & 17.8 \\
\hline 1983 & 14.6 \\
\hline 1984 & 14.8 \\
\hline 1985 & 13.1 \\
\hline 1986 & 10.5 \\
\hline 1987 & 9.1 \\
\hline 1988 & 9.5 \\
\hline 1989 & 10.3 \\
\hline 1990 & 9.5 \\
\hline 1991 & 9.7 \\
\hline 1992 & 10.2 \\
\hline 1993 & 9.5 \\
\hline 1994 & 7.9 \\
\hline Average & 11.7 \\
\hline Standard Deviation & 2.6 \\
\hline Deduction for personal expenses** & 88.3 \\
\hline
\end{tabular}

- Savings rate is calculated by dividing personal saving by personal disposable income.

* Deduction for personal expenses $=100 \%$ - average savings rate. 
Table A2

SAVINGS RATE ${ }^{\text {GS }}$

PROJECTION (1995-2017)

\begin{tabular}{|c|c|}
\hline Year & \% Savings Rate* \\
\hline 1995 & 6.9 \\
\hline 1996 & 6.2 \\
\hline 1997 & 6.1 \\
\hline 1998 & 6.1 \\
\hline 1999 & 6.1 \\
\hline 2000 & 6.2 \\
\hline 2001 & 6.4 \\
\hline 2002 & 6.5 \\
\hline 2003 & 6.6 \\
\hline 2004 & 6.7 \\
\hline 2005 & 6.9 \\
\hline 2006 & 7.1 \\
\hline 2007 & 7.2 \\
\hline 2008 & 7.3 \\
\hline 2009 & 7.4 \\
\hline 2010 & 7.5 \\
\hline 2011 & 7.6 \\
\hline 2012 & 7.7 \\
\hline 2013 & 7.9 \\
\hline 2014 & 8.0 \\
\hline 2015 & 8.2 \\
\hline 2106 & 8.3 \\
\hline 2017 & 8.3 \\
\hline Average & 7.1 \\
\hline \hline Standard Deviation & 0.8 \\
\hline Deduction for personal expenses** & 92.9 \\
\hline
\end{tabular}

* Savings rate is calculated by dividing personal saving by personal disposable income.

** Deduction for personal expenses $=100 \%$ - average savings rate. 